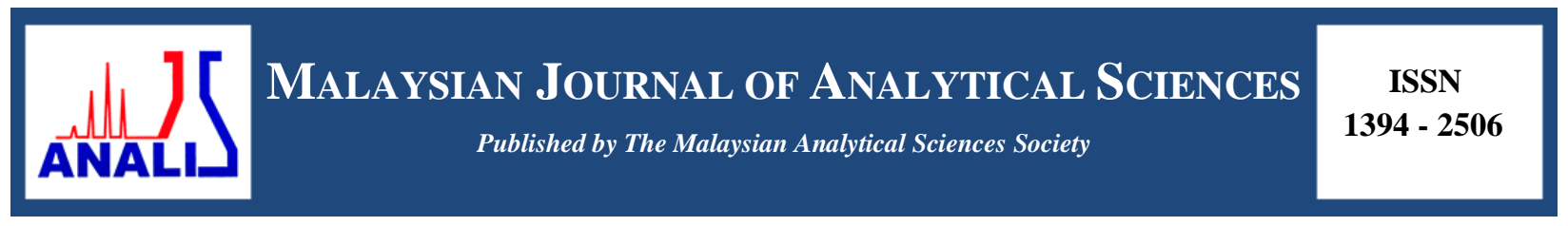

\title{
SYNTHESIS, CHARACTERISATION AND EFFECT OF TEMPERATURE ON CORROSION INHIBITION BY THIOSEMICARBAZONE DERIVATIVES AND ITS TIN(IV) COMPLEXES
}

\author{
(Sintesis, Pencirian dan Kesan Suhu Ke atas Perencatan Kakisan oleh Ligan Terbitan \\ Tiosemikarbazon dan Kompleks Timah(IV))
}

\author{
Nur Nadira Hazani ${ }^{1,2}$, Nur Nadia Dzulkifli ${ }^{1 *}$, Sheikh Ahmad Izaddin Sheikh Mohd Ghazali ${ }^{1}$, Yusairie Mohd ${ }^{2}$ \\ Yang Farina ${ }^{3}$, Nurul 'Ain Jamion' \\ ${ }^{I}$ Faculty of Applied Sciences, \\ Universiti Teknologi MARA, Kampus Kuala Pilah, 72000 Kuala Pilah, Negeri Sembilan, Malaysia \\ ${ }^{2}$ Faculty of Applied Sciences, \\ Universiti Teknologi MARA, 40450 Shah Alam, Selangor, Malaysia \\ ${ }^{3}$ Faculty of Science and Technology, \\ Universiti Kebangsaan Malaysia, 43600 UKM Bangi, Selangor, Malaysia \\ *Corresponding author: nurnadia@ns.uitm.edu.my
}

Received: 29 August 2017; Accepted: 5 August 2018

\begin{abstract}
Thiosemicarbazone derivatives and its tin(IV) complexes used in this study were 2-acetylpyridine 4-ethyl-3-thiosemicarbazone (HAcETSc), 2-acetylpyridine 4-methyl-3-thiosemicarbazone (HAcMTSc), 2-acetylpyridine 4-ethyl-3-thiosemicarbazone dichlorophenyltin $\left(\mathrm{Sn}(\mathrm{HAcETSc}) \mathrm{PhenCl}_{2}\right)$, and 2-acetylpyridine 4-methyl-3-thiosemicarbazone dichlorophenyltin $\left(\mathrm{Sn}(\mathrm{HAcMTSc}) \mathrm{PhenCl}_{2}\right.$ ). All these title compounds were characterised using an elemental analyser, Fourier-transform infraredattenuated total reflectance spectroscopy (FTIR-ATR), ultraviolet-visible spectroscopy (UV-Vis), and nuclear magnetic resonance (NMR). The efficiency of the synthesised compounds as a corrosion inhibitor of mild steel in $1.0 \mathrm{M} \mathrm{HCl}$ was investigated using weight loss technique at different concentrations, 1,2 , and $3 \mathrm{mM}$, and at a temperature range of $30-60{ }^{\circ} \mathrm{C}$. The thiosemicarbazone ligand and its tin(IV) complexes affirmed the hypothesis where the inhibitor efficiency tends to increase as the inhibitor concentration increases, indicating their potential use as a corrosion inhibitor for mild steel. Moreover, inhibitor efficiency decreases when temperature increases.
\end{abstract}

Keywords: thiosemicarbazone, corrosion inhibitor, temperature, mild steel

\begin{abstract}
Abstrak
Terbitan tiosemikarbazon dan kompleks timah(IV) yang digunakan dalam kajian ini adalah 2-asetilpiridina 4-etil-3tiosemikarbazon (HAcETSc), 2-asetilpiridina 4-metil-3-tiosemikarbazon (HAcMTSc), 2-asetilpiridina 4-etil-3-tiosemikarbazon dikloridastanum $\left(\mathrm{Sn}(\mathrm{HAcETSc}) \mathrm{PhenCl}_{2}\right)$ and 2-asetilpiridina 4-metil-3-tiosemikarbazon dikloridastanum ( $\mathrm{Sn}(\mathrm{HAcMTSc}) \mathrm{PhenCl}_{2}$ ). Kesemua sebatian telah dicirikan menggunakan analisis unsur, spektroskopi inframerah transformasi Fourier-pantulan keseluruhan dikecilkan (FTIR-ATR), spektroskopi ultralembayung-sinar nampak (UV-Vis) dan resonans magnetik nuklear (NMR). Kecekapan sebatian yang telah disintesis dikaji sebagai perencat kakisan terhadap keluli lembut dalam 1.0 M HCl dengan kepekatan berbeza, 1, 2, dan $3 \mathrm{mM}$, serta suhu antara 30-60 ${ }^{\circ} \mathrm{C}$ menggunakan kaedah kesusutan berat. Ligan tiosemikarbazon dan kompleks timah(IV) membuktikan hipotesis di mana kecekapan perencat cenderung untuk meningkat apabila kepekatan perencat meningkat, menunjukkan ia berpotensi untuk digunakan sebagai perencat kakisan terhadap keluli lembut. Tambahan lagi, kecekapan perencat menurun apabila suhu meningkat.
\end{abstract}




\section{Nur Nadira et al: SYNTHESIS, CHARACTERISATION AND EFFECT OF TEMPERATURE ON CORROSION INHIBITION BY THIOSEMICARBAZONE DERIVATIVES AND ITS TIN(IV) COMPLEXES}

Kata kunci: tiosemikarbazon, perencatan kakisan, suhu, keluli lembut

\section{Introduction}

Corrosion inhibitor is one of the methods used to prevent corrosion [1]. Inhibitors are compounds used in low concentration and applied in an aggressive environment to protect or slow down corrosion [2,3]. Finding new corrosion inhibitors, which have high efficiency, are easy-to-make, and cheap, have attracted many researchers' attention [4]. In the industrial sector, building surface corrosion occurs from common activities such as acid pickling, acid descaling, and industrial acid cleaning, where an acid solution, such as hydrochloric acid, is used to remove undesirable scale or rust. This activity causes metal dissolution due to the attack of the aggressive media. A corrosion inhibitor containing heteroatoms of nitrogen $(\mathrm{N})$, sulphur $(\mathrm{S})$, and oxygen $(\mathrm{O})$, as well as an aromatic group in its structure, is considered effective and has the potential as a corrosion inhibitor [5, 6]. Through adsorption process, the inhibitor forms a protective layer and offers a barrier from corrosive attack on the metal surface [7, 8].

Thiosemicarbazone (TSC) derivatives and tin complexes have been reported to be potential corrosion inhibitors due to the presence of nitrogen and sulphur atoms, which could increase inhibition efficiency [9]. Furthermore, tin complexes with thiosemicarbazone derivatives have received a great attention as a corrosion inhibitor, since organotin is recognised for its biocidal behaviour, friction and wear reducing properties, as well as corrosioninhibiting characteristics $[10,11]$. Therefore, this study aims to synthesise and characterise new compounds for their expected anticorrosion activity. The synthesised ligands and complexes were tested as potential corrosion inhibitors in $1.0 \mathrm{M} \mathrm{HCl}$. The compounds under investigation are listed in Table 1.

Table 1. Compounds under investigation

\begin{tabular}{|c|c|c|c|}
\hline Inhibitor & Abbreviation & Structure & $\begin{array}{c}\text { Molar Mass } \\
(\mathrm{g} / \mathrm{mol})\end{array}$ \\
\hline $\begin{array}{l}\text { 2-acetylpyridine 4-ethyl- } \\
\text { 3-thiosemicarbazone }\end{array}$ & HAcETSc & $\mathrm{CH}_{3}$ & 222 \\
\hline $\begin{array}{l}\text { 2-acetylpyridine 4- } \\
\text { methyl-3- } \\
\text { thiosemicarbazone }\end{array}$ & HAcMTSc & $\mathrm{CH}_{3}$ & 208 \\
\hline $\begin{array}{l}\text { 2-acetylpyridine 4-ethyl- } \\
\text { 3-thiosemicarbazone } \\
\text { dichlorophenyltin }\end{array}$ & $\mathrm{Sn}(\mathrm{HAcETSc}) \mathrm{PhenCl}_{2}$ & $\mathrm{CH}_{3}$ & 486 \\
\hline
\end{tabular}


Table 1 (cont'd). Compounds under investigation

\begin{tabular}{llll}
\hline Inhibitor & Abbreviation & Structure & $\begin{array}{c}\text { Molar Mass } \\
(\mathbf{g} / \mathbf{m o l})\end{array}$ \\
\hline $\begin{array}{l}\text { 2-acetylpyridine 4- } \\
\text { methyl-3- } \\
\text { thiosemicarbazone } \\
\text { dichlorophenyltin }\end{array}$ & $\mathrm{Sn}(\mathrm{HAcMTSc}) \mathrm{PhenCl}_{2}$
\end{tabular}

Material and measurement

\section{Materials and Methods}

All chemicals used were commercially purchased without further purification. The melting point was measured using a melting point apparatus (model SMP10 Stuart) and was taken in an open capillary tube. The elemental analysis of synthesised compounds was performed using CHNS/O Model Fision EA 1180 and Thermo Finnigan Flash EA 1112 Series. Meanwhile, the infrared spectra were recorded on Fourier-transform infrared-attenuated total reflectance (FTIR-ATR) Perkin Elmer spectrophotometer. The electronic absorption spectra were recorded on a PG Instrument T80/T80+ spectrophotometer in the 200-600 nm region using dimethyl sulfoxide (DMSO) as a solvent. ${ }^{1} \mathrm{H}$ and ${ }^{13} \mathrm{C}$ NMR spectra were measured on a Bruker spectrophotometer using deuterated dimethyl sulfoxide (DMSO- $\mathrm{d}_{6}$ ) as a solvent and tetramethylsilane as an internal reference.

\section{Synthesis of ligands}

An ethanoic solution of 2-acetylpyridine $(1 \mathrm{mmol})$ and ethanoic solution of 4-ethyl-3-thiosemicarbazide or 4methyl-3-thiosemicarbazide $(1 \mathrm{mmol})$ were mixed together, and then a few drops of acetic acid were added to the mixture. The mixture was refluxed for $2 \mathrm{~h}$ with a constant stirring rate of $400 \mathrm{rpm}$ at a temperature between $60-70$ ${ }^{\circ} \mathrm{C}$. The product was cooled after $2 \mathrm{~h}$ and kept at room temperature to obtain a crystalline product. The crystalline product formed was filtered, washed with cold ethanol, and dried over silica gel.

\section{Synthesis of tin(IV) complexes}

The synthesised ligand $(1 \mathrm{mmol})$ was dissolved in ethanol and the metal salt, phenyltin trichloride $(1 \mathrm{mmol})$, was dissolved in distilled water. The metal salt was added dropwise to the ethanoic solution ligand with constant stirring at $400 \mathrm{rpm}$. The reaction mixture was continuously stirred for 4 hours. The precipitate was then filtered and washed with cold ethanol. The precipitate formed was left to dry over silica gel. The weight of the precipitate was recorded.

\section{Corrosion inhibition study - weight loss technique}

The aggressive solution, $1 \mathrm{M}$ hydrochloric acid $(\mathrm{HCl}), 37 \%$ of analytical grade was prepared via dilution with distilled water. The inhibitor with concentrations of 1,2 , and $3 \mathrm{mM}$ were also prepared by diluting the stock solution, $1 \mathrm{M} \mathrm{HCl}$. The determination of weight loss on mild steel was tested for 24 hours at $30{ }^{\circ} \mathrm{C}$. The experiment was conducted in triplicate and the average mass was calculated. The experiment was repeated at different temperatures of 40,50 , and $60^{\circ} \mathrm{C}$. 


\section{Nur Nadira et al: SYNTHESIS, CHARACTERISATION AND EFFECT OF TEMPERATURE ON CORROSION INHIBITION BY THIOSEMICARBAZONE DERIVATIVES AND ITS TIN(IV) COMPLEXES}

\section{Physical measurement}

\section{Results and Discussion}

The physical characteristics of the synthesised ligands and complexes, namely yield percentage, colour, melting point, molar conductivity, and elemental percentage are shown in Table 2. The complexes have a higher melting point compared to the ligands. The molar conductivities for both complexes are in the range of $4.0-12.5 \mathrm{Scm}^{2} . \mathrm{mol}^{-1}$, which indicates non-electrolyte behaviour [12]. The elemental analysis of calculated and experimental data is in good agreement.

Table 2. Physical characteristics of synthesised ligands and complexes

\begin{tabular}{|c|c|c|c|c|c|c|c|c|}
\hline \multirow[t]{2}{*}{ Compound } & \multirow{2}{*}{$\begin{array}{c}\text { Percentage } \\
\text { Yield } \\
(\%)\end{array}$} & \multirow[t]{2}{*}{ Colour } & \multirow{2}{*}{$\begin{array}{c}\text { Melting } \\
\text { Points } \\
\left({ }^{\circ} \mathrm{C}\right)\end{array}$} & \multirow{2}{*}{$\begin{array}{c}\text { Molar } \\
\text { Conductivity } \\
\left(\mathrm{Scm}^{2} \cdot \mathrm{mol}^{-1}\right)\end{array}$} & \multicolumn{4}{|c|}{$\begin{array}{l}\text { Elemental Analysis } \\
\text { (Experimental) }(\%)\end{array}$} \\
\hline & & & & & $\mathbf{C}$ & $\mathbf{H}$ & $\mathbf{N}$ & $\mathbf{S}$ \\
\hline HAcETSc & 88.06 & $\begin{array}{l}\text { Light } \\
\text { yellow }\end{array}$ & $127-130$ & - & $\begin{array}{c}54.05 \\
(53.34)\end{array}$ & $\begin{array}{c}6.31 \\
(7.41)\end{array}$ & $\begin{array}{l}25.23 \\
(24.50\end{array}$ & $\begin{array}{c}14.42 \\
(14.67)\end{array}$ \\
\hline HAcMTSc & 71.61 & $\begin{array}{l}\text { Light } \\
\text { yellow }\end{array}$ & $176-177$ & - & $\begin{array}{l}51.56 \\
(51.92)\end{array}$ & $\begin{array}{c}5.88 \\
(5.77)\end{array}$ & $\begin{array}{l}28.06 \\
(26.92)\end{array}$ & $\begin{array}{c}14.55 \\
(15.38)\end{array}$ \\
\hline $\mathrm{Sn}(\mathrm{HAcETSc}) \mathrm{PhenCl}_{2}$ & 63.37 & Yellow & $232-235$ & 7.5 & $\begin{array}{c}39.51 \\
(39.94)\end{array}$ & $\begin{array}{c}3.70 \\
(3.81)\end{array}$ & $\begin{array}{c}11.52 \\
(11.91)\end{array}$ & $\begin{array}{c}6.58 \\
(6.34)\end{array}$ \\
\hline $\mathrm{Sn}(\mathrm{HAcMTSc}) \mathrm{PhenCl}_{2}$ & 56.14 & Yellow & $242-245$ & 5.2 & $\begin{array}{c}38.14 \\
(37.59)\end{array}$ & $\begin{array}{c}3.39 \\
(3.39)\end{array}$ & $\begin{array}{c}11.86 \\
(11.83)\end{array}$ & $\begin{array}{c}6.78 \\
(6.28)\end{array}$ \\
\hline
\end{tabular}

\section{Infrared spectra}

The tentative assignments to the significant IR spectral bands of ligands and complexes are presented in Table 3 and Table 4, respectively. The infrared spectra for compounds HAcETSc and $\mathrm{Sn}(\mathrm{HAcETSc}) \mathrm{PhenCl}_{2}$ are shown in Figure 1, whereas the infrared spectra for compounds HAcMTSc and $\mathrm{Sn}(\mathrm{HAcMTSc}) \mathrm{PhenCl}_{2}$ are shown in Figure 2. Thiosemicarbazone ligand contains thiomide, a $\mathrm{C}=\mathrm{S}$ functional group, which is known to exist as a thione-thiol tautomerism. Nonetheless, the absence of S-H stretching band of $2500-2600 \mathrm{~cm}^{-1}$ indicates that the ligand is in a thione form [13]. Several significant changes in spectral complexes and ligands suggest the coordination of TSC ligands to metal ion through azomethine nitrogen and thiolate sulphur. In the spectra of ligands, the stretching bands at 3210 and $3240 \mathrm{~cm}^{-1}$ for compounds HAcETSc and HAcMTSc, respectively, correspond to the $v(\mathrm{~N}-\mathrm{H})$ group that disappeared, and a new stretching band appeared in the spectra of complexes, which is attributed to $v(\mathrm{C}=\mathrm{N})$ stretching band due to thioenolisation of $\mathrm{C}=\mathrm{S}[14]$.

Moreover, changes can be observed through the shifting of some bands. The shifting of $v\left(C=N_{p y}\right)$ stretching band to higher frequency from the spectra of ligand indicates the involvement of pyridine azomethine nitrogen in coordination with metal ion. Besides, $v(\mathrm{C}=\mathrm{N})$ observed at 1527 and $1537 \mathrm{~cm}^{-1}$ in both ligands shifted to 1504 and $1557 \mathrm{~cm}^{-1}$, respectively, in the spectra of complexes, indicating that the coordination occurred through azomethine nitrogen.

The stretching bands due to $v(\mathrm{C}=\mathrm{S})$ at $1084 \mathrm{~cm}^{-1}$ [compound HAcETSc] and $1074 \mathrm{~cm}^{-1}$ [compound HAcMTSc] disappeared in the spectra of complexes and new stretching bands, C-S appeared at $1061 \mathrm{~cm}^{-1}$ [compound $\mathrm{Sn}(\mathrm{HAcETSc}) \mathrm{PhenCl}_{2}$ ] and $1047 \mathrm{~cm}^{-1}$ [compound $\mathrm{Sn}(\mathrm{HAcMTSc}) \mathrm{PhenCl}_{2}$ ], indicating that the coordination occurred through thiolate sulphur after enolisation of $\mathrm{C}=\mathrm{S}$ functional group and followed by deprotonation on sulphur [15]. Nevertheless, the new stretching bands at $310-360 \mathrm{~cm}^{-1}, 258-327 \mathrm{~cm}^{-1}$, and $330-354 \mathrm{~cm}^{-1}$ were assigned to $v(\mathrm{Sn}-\mathrm{N}), v\left(\mathrm{Sn}-\mathrm{N}_{\mathrm{py}}\right)$, and $v(\mathrm{Sn}-\mathrm{S})$, respectively, and the stretching band at $229-270 \mathrm{~cm}^{-1}$ range was assigned to $v(\mathrm{Sn}-\mathrm{Cl})[16]$. The existence of these new stretching bands indicates the coordination of ligands to metal ion. 
Table 3. IR spectral data of the ligand and complexes $\left(\mathrm{cm}^{-1}\right)$

\begin{tabular}{lccccccc}
\hline Compound & $\mathbf{v}(\mathbf{N}-\mathbf{H})$ & $\mathbf{v}\left(\mathbf{C}=\mathbf{N}_{\mathbf{p y}}\right)$ & $\mathbf{v}(\mathbf{C}=\mathbf{N})$ & $\mathbf{v}(\mathbf{N}-\mathbf{N})$ & $\mathbf{v}(\mathbf{C}-\mathbf{N})$ & $\mathbf{v}(\mathbf{C}=\mathbf{S})$ & $\mathbf{v}(\mathbf{C}-\mathbf{S})$ \\
\hline HAcETSc & 3349,3210 & 1580 & 1527 & 1297 & 1221 & 1084 & - \\
HAcMTSc & 3288,3240 & 1578 & 1537 & 1295 & 1230 & 1074 & - \\
Sn(HAcETSc)PhenCl & 3372 & 1601 & 1504,1587 & 1283 & 1247 & - & 1061 \\
Sn(HAcMTSc)PhenCl & 3297 & 1601 & 1557,1587 & 1290 & 1256 & - & 1047 \\
\hline
\end{tabular}

Table 4. Far-IR spectral data of the complexes $\left(\mathrm{cm}^{-1}\right)$

\begin{tabular}{lcccc}
\hline Compound & $\mathbf{v}(\mathbf{S n}-\mathbf{N})$ & $\mathbf{v}(\mathbf{S n}-\mathbf{S})$ & $\mathbf{v}\left(\mathbf{S n}-\mathbf{N}_{\mathbf{p y}}\right)$ & $\mathbf{v}(\mathbf{S n}-\mathbf{C l})$ \\
\hline $\mathrm{Sn}(\mathrm{HAcETSc}) \mathrm{PhenCl}_{2}$ & 331 & 354 & 289 & 267 \\
$\mathrm{Sn}\left(\mathrm{HAcMTSc}_{\mathrm{PhenCl}}\right.$ & 328 & 357 & 289 & 265 \\
\hline
\end{tabular}

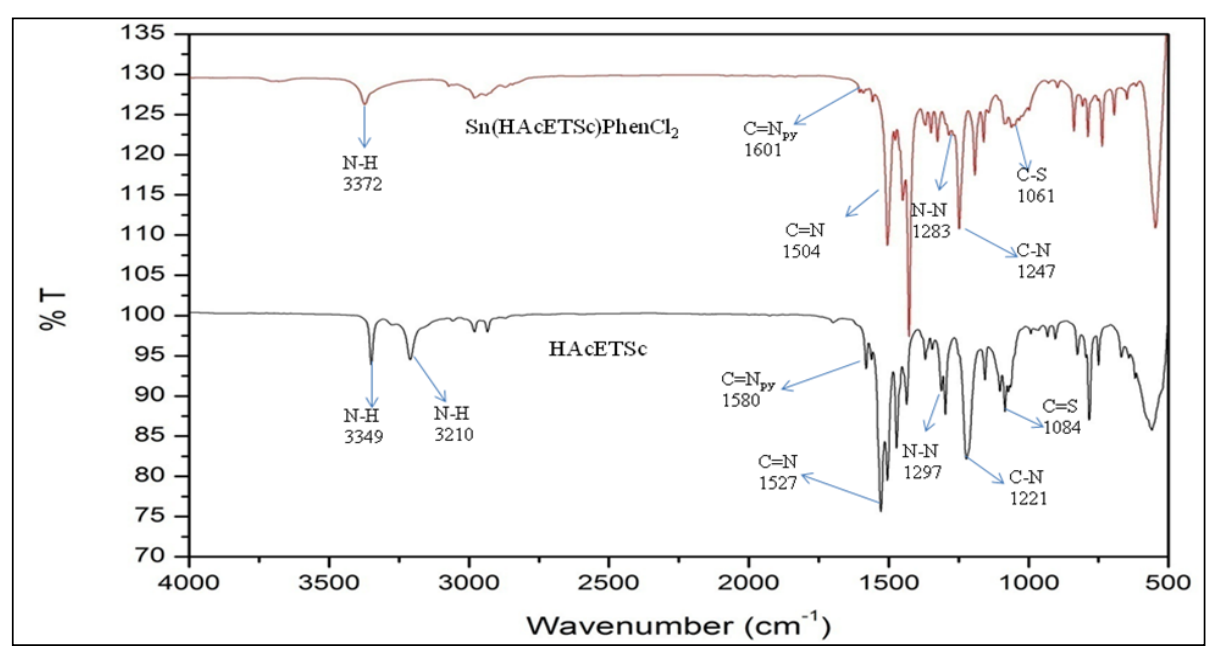

Figure 1. Infrared spectra for compound HAcETSc and $\mathrm{Sn}(\mathrm{HAcETSc}) \mathrm{PhenCl}_{2}$

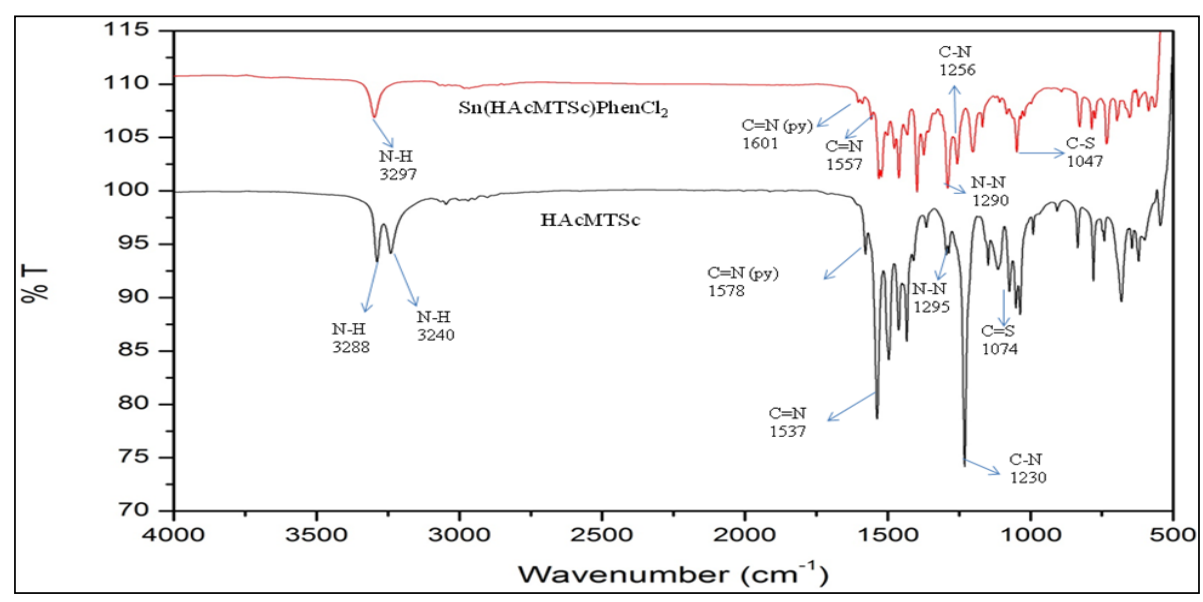

Figure 2. Infrared spectra for compound HAcMTSc and $\mathrm{Sn}(\mathrm{HAcMTSc}) \mathrm{PhenCl}_{2}$ 


\section{Nur Nadira et al: SYNTHESIS, CHARACTERISATION AND EFFECT OF TEMPERATURE ON CORROSION INHIBITION BY THIOSEMICARBAZONE DERIVATIVES AND ITS TIN(IV) COMPLEXES}

\section{Electronic spectra}

The UV-Visible (UV-Vis) absorption spectra for compounds HAcETSc and $\mathrm{Sn}(\mathrm{HAcETSc}) \mathrm{PhenCl}_{2}$ are shown in Figure 3, whereas the UV-Vis absorption spectra for compounds HAcMTSc and $\mathrm{Sn}(\mathrm{HAcMTSc}) \mathrm{PhenCl}_{2}$ are shown in Figure 4. For both ligands, there is only one absorption peak at $320 \mathrm{~nm}$ and assigned to $\mathrm{n} \rightarrow \pi^{*}$ transition. This band corresponds to the $\mathrm{C}=\mathrm{S}$ and $\mathrm{C}=\mathrm{N}$ groups. The absorption peak attributed to $\pi \rightarrow \pi^{*}$ transition might not be observed in the ligand spectrum as $\mathrm{n} \rightarrow \pi^{*}$ transition in $\mathrm{C}=\mathrm{S}$ and $\mathrm{C}=\mathrm{N}$ has stronger absorption and might cover $\pi \rightarrow \pi^{*}$ transition [17]. Upon complexation, two absorption peaks were observed at 315 and $400 \mathrm{~nm}$ [compound $\mathrm{Sn}(\mathrm{HAcETSc}) \mathrm{PhenCl}_{2}$ ], as well as at 305 and $405 \mathrm{~nm}$ [compound $\mathrm{Sn}(\mathrm{HAcMTSc}) \mathrm{PhenCl}_{2}$ ], which were appointed to $\mathrm{n} \rightarrow \pi^{*}$ transition and the ligand to metal charge transfer (LMCT), respectively. Moreover, both complexes underwent a hypsochromic shift. The spectra shifting shows the donation of electron lone pair from $\mathrm{N}$ or $\mathrm{S}$ to the metal ion [18].

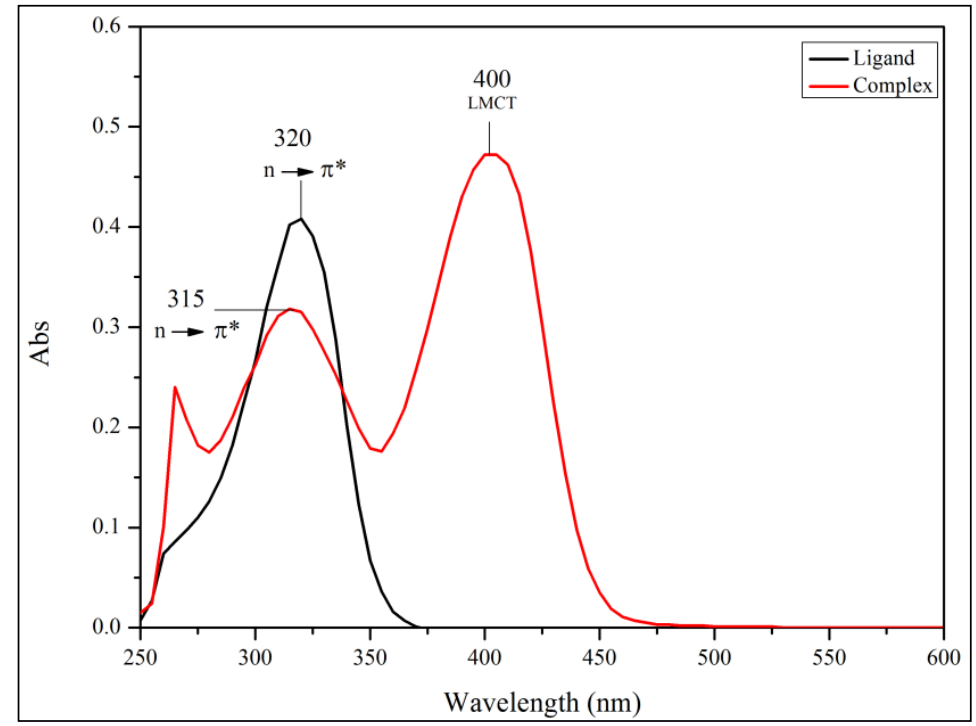

Figure 3. UV-Vis absorption spectra for compound HAcETSc and $\mathrm{Sn}(\mathrm{HAcETSc}) \mathrm{PhenCl}_{2}$

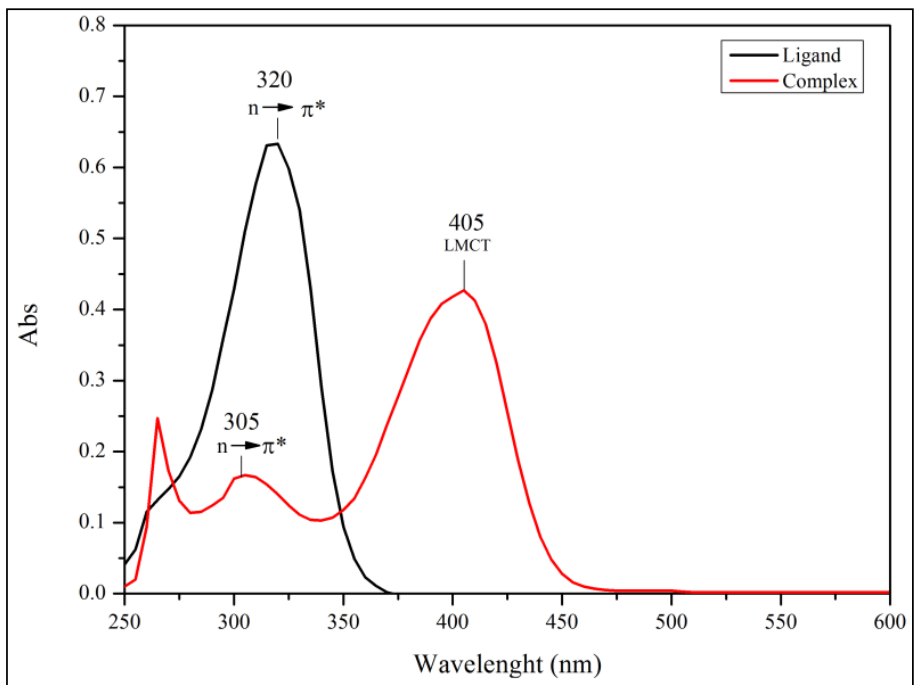

Figure 4. UV-Vis absorption spectra for compound HAcMTSc and $\mathrm{Sn}(\mathrm{HAcMTSc}) \mathrm{PhenCl}_{2}$ 
${ }^{1} \mathrm{H}$ and ${ }^{13} \mathrm{C}$ NMR spectra

${ }^{1} \mathrm{H}$ and ${ }^{13} \mathrm{C}$ NMR spectral data of the ligands and complexes are tabulated in Table 5 and 6 , respectively. For ligands HAcETSc and HAcMTSc, $\mathrm{N}(1) \mathrm{H}$ signal appeared as a triplet at 8.68 and $8.62 \mathrm{ppm}$, respectively. Meanwhile, $\mathrm{N}(2) \mathrm{H}$ signal appeared as a singlet at $10.25 \mathrm{ppm}$ for both ligands. Upon complexation, the peak of $\mathrm{N}(1) \mathrm{H}$ shifted downfield with a small shifting value and $\mathrm{N}(2) \mathrm{H}$ signal disappeared due to deprotonation of the ligands when coordinated to the metal ion. Furthermore, $\mathrm{CH}_{3}-\mathrm{C}=\mathrm{N}$ signal of complexes showed about $0.4 \mathrm{ppm}$ shift downfield as compared to the ligand, which revealed the involvement of an azomethine nitrogen in coordination to the metal ion. Multiplets signal were found for aromatic ring proton. The aromatic ring proton signals shifted downfield upon complexation with metal [19].

In ${ }^{13} \mathrm{C} N M R$, the signal of $\mathrm{C}=\mathrm{S}$ and $\mathrm{C}=\mathrm{N}$ groups shifted to the upfield region in the complexes as compared to the ligands, which proved that the coordination occurred through $\mathrm{N}=\mathrm{C}-\mathrm{S}^{-}$and nitrogen atom of pyridine group to the metal ion. Moreover, the coordination to metal ion occurred via an azomethine nitrogen was proven when the $\mathrm{CH}_{3^{-}}$ $\mathrm{C}=\mathrm{N}$ signal of the complexes shifted to downfield region, in comparison with the ligands. There were extra signals present, which are represented as a phenyl ring [20].

Table 5. ${ }^{1} \mathrm{H}$ NMR spectral data (ppm) of the ligands and complexes

\begin{tabular}{lcccccc}
\hline \multirow{2}{*}{ Compound } & \multicolumn{5}{c}{ Chemical shift, $\boldsymbol{\delta}(\mathbf{p p m})$} \\
\cline { 2 - 7 } & $\mathbf{N}(\mathbf{1}) \mathbf{H}$ & $\mathbf{N}(\mathbf{2}) \mathbf{H}$ & $\mathbf{- \mathbf { C H } _ { \mathbf { 3 } }}$ & $\mathbf{C H}_{\mathbf{3}} \mathbf{- C}=\mathbf{N}$ & $\mathbf{- C H}_{\mathbf{2}}$ & Aromatic \\
\hline HAcETSc & 8.68 & 10.25 & 1.16 & 2.38 & 3.64 & $7.36-8.58$ \\
HAcMTSc & 8.62 & 10.25 & 3.05 & 2.38 & - & $7.37-8.59$ \\
$\mathrm{Sn}(\mathrm{HAcETSc}) \mathrm{PhenCl}_{2}$ & 8.70 & - & 1.22 & 2.78 & 3.55 & $7.52-8.70$ \\
$\mathrm{Sn}(\mathrm{HAcMTSc}) \mathrm{PhenCl}_{2}$ & 8.68 & - & 3.02 & 2.79 & - & $7.51-8.68$ \\
\hline
\end{tabular}

Table $6 .{ }^{13} \mathrm{C}$ NMR spectral data (ppm) of the ligands complexes

\begin{tabular}{|c|c|c|c|c|c|c|}
\hline \multirow{2}{*}{ Compound } & \multicolumn{6}{|c|}{ Chemical shift, $\delta$ (ppm) } \\
\hline & $\mathrm{C}=\mathrm{S}$ & $\mathrm{C}=\mathrm{N}$ & $-\mathrm{CH}_{3}$ & $\mathrm{CH}_{3} \mathrm{C}=\mathrm{N}$ & $-\mathrm{CH}_{2}$ & Phenyl Ring \\
\hline HAcETSc & 178.10 & 155.17 & 14.93 & 12.59 & 39.01 & $121.26-148.93$ \\
\hline HAcMTSc & 179.18 & 155.22 & 31.63 & 12.56 & - & $121.24-148.93$ \\
\hline $\mathrm{Sn}(\mathrm{HAcETSc}) \mathrm{PhenCl}_{2}$ & 168.76 & 135.77 & 15.05 & 14.46 & 37.80 & $\begin{array}{l}142.24-144.87 \\
125.91-130.71\end{array}$ \\
\hline $\mathrm{Sn}(\mathrm{HAcMTSc}) \mathrm{PhenCl}_{2}$ & 169.43 & 135,76 & 29.63 & 15.10 & - & $\begin{array}{l}142.52-144.86 \\
125.96-130.73\end{array}$ \\
\hline
\end{tabular}

\section{Corrosion inhibition study}

The inhibitor efficiency of mild steel in $1 \mathrm{M} \mathrm{HCl}$ at different temperatures and different concentrations was investigated by weight loss method, in the presence and absence of inhibitors. The values of inhibitor efficiency are given in Table 7. The results showed that the inhibition efficiency increased when the concentration of inhibitor increased. Apart from that, the title compounds showed a decreasing efficiency at higher temperature $\left(60{ }^{\circ} \mathrm{C}\right)$. The results were different at certain temperatures for each compound. For instance, at concentration $3 \mathrm{mM}$, compound HAcETSc had better efficiency at $50{ }^{\circ} \mathrm{C}$ while other compounds worked better at $40{ }^{\circ} \mathrm{C}$. 


\section{Nur Nadira et al: SYNTHESIS, CHARACTERISATION AND EFFECT OF TEMPERATURE ON CORROSION INHIBITION BY THIOSEMICARBAZONE DERIVATIVES AND ITS TIN(IV) COMPLEXES}

Table 7. Inhibitor efficiency at different concentrations in $1 \mathrm{M} \mathrm{HCl}$ at different temperatures

\begin{tabular}{|c|c|c|c|c|c|}
\hline \multirow{2}{*}{ Concentration } & \multirow{2}{*}{ Compounds } & \multicolumn{4}{|c|}{ Inhibitor Efficiency (\%) } \\
\hline & & $30{ }^{\circ} \mathbf{C}$ & $40{ }^{\circ} \mathrm{C}$ & $50{ }^{\circ} \mathbf{C}$ & $60{ }^{\circ} \mathbf{C}$ \\
\hline \multirow{4}{*}{$3 \mathrm{mM}$} & HAcETSc & 84.74 & 91.09 & 96.08 & 84.80 \\
\hline & HAcMTSc & 84.32 & 95.91 & 83.80 & 80.48 \\
\hline & $\mathrm{Sn}(\mathrm{HAcETSc}) \mathrm{PhenCl}_{2}$ & 86.44 & 89.88 & 81.61 & 73.32 \\
\hline & $\mathrm{Sn}(\mathrm{HAcMTSc}) \mathrm{PhenCl}_{2}$ & 94.78 & 95.98 & 95.46 & 87.33 \\
\hline \multirow{4}{*}{$2 \mathrm{mM}$} & HAcETSc & 84.32 & 88.94 & 85.27 & 84.10 \\
\hline & HAcMTSc & 78.67 & 78.00 & 81.06 & 76.10 \\
\hline & $\mathrm{Sn}(\mathrm{HAcETSc}) \mathrm{PhenCl}_{2}$ & 79.52 & 87.32 & 71.84 & 40.95 \\
\hline & $\mathrm{Sn}(\mathrm{HAcMTSc}) \mathrm{PhenCl}_{2}$ & 85.03 & 94.57 & 92.30 & 53.58 \\
\hline \multirow{4}{*}{$1 \mathrm{mM}$} & HAcETSc & 81.92 & 77.48 & 82.93 & 67.61 \\
\hline & HAcMTSc & 42.51 & 66.03 & 72.32 & 61.56 \\
\hline & $\mathrm{Sn}(\mathrm{HAcETSc}) \mathrm{PhenCl}_{2}$ & 54.52 & 80.14 & 57.58 & 34.76 \\
\hline & $\mathrm{Sn}(\mathrm{HAcMTSc}) \mathrm{PhenCl}_{2}$ & 81.53 & 84.38 & 91.41 & 45.22 \\
\hline
\end{tabular}

At $30{ }^{\circ} \mathrm{C}$, the highest percentage of inhibitor efficiency is as follows: $\mathrm{Sn}(\mathrm{HAcMTSc}) \mathrm{PhenCl}_{2}>\mathrm{Sn}(\mathrm{HAcETSc})$ $\mathrm{PhenCl}_{2}>\mathrm{HAcETSc}>\mathrm{HAcMTSc}$. The efficiency for compound $\mathrm{Sn}(\mathrm{HAcMTSc}) \mathrm{PhenCl}_{2}$ at $30{ }^{\circ} \mathrm{C}$ was $94.78 \%$; the value increased slightly at $40{ }^{\circ} \mathrm{C}$ and started to decrease until $60{ }^{\circ} \mathrm{C}$ with the efficiency of $87.33 \%$. Similarly, for compounds HAcMTSc and $\mathrm{Sn}(\mathrm{HAcETSc}) \mathrm{PhenCl}_{2}$, its efficiency increased at $40{ }^{\circ} \mathrm{C}$ but became less efficient with increasing temperature. For compound HAcETSc, the efficiency kept increasing until the temperature was $50{ }^{\circ} \mathrm{C}$ and decreased at $60^{\circ} \mathrm{C}$. Even though the efficiency is low at higher temperature, it is still able to protect mild steel in the acid solution from corroding as compared to the blank of $1 \mathrm{M} \mathrm{HCl} \mathrm{[21].}$

Generally, the effects of a compound to provide better protection on mild steel surface are due to the presence of electron pairs, which are sulphur and nitrogen atoms, $\pi$-electrons on the aromatic rings, molecular size, and the formation of metallic complexes [22, 23]. Hence, it can be recommended that compound $\mathrm{Sn}(\mathrm{HAcMTSc})-\mathrm{PhenCl}_{2}$ is efficient in preventing mild steel dissolution as compared to other studied compounds

\section{Conclusion}

The thiosemicarbazone derivative ligands derived from 2-acetylpyridine and tin(IV) complexes have been successfully synthesised through condensation process. The ligands and complexes were characterised by using CHNS, FTIR, UV-Vis, and NMR. From the characterisation of the complexes, it has been determined that ligand acts as tridentate to metal ions, which coordinates through azomethine nitrogen and thiolate sulphur. The outcome for the corrosion study showed good inhibitive properties for mild steel corrosion and the inhibitor efficiency increased as the inhibitor concentration increased. For temperature effect, the inhibitor efficiency decreased at high temperature. This work suggests that the corrosion inhibition study should undergo further study using electrochemical impedance spectroscopy (EIS) and linear polarisation resistance (LPR) to confirm the corrosion efficiency based on the study done using weight loss technique.

\section{Acknowledgement}

The authors would like to thank the Faculty of Applied Sciences, Universiti Teknologi MARA, Negeri Sembilan, the Faculty of Science and Technology, Universiti Kebangsaan Malaysia, as well as the Centre of Research and Instrumentation (CRIM) for the research facilities. The authors are also grateful for the research grant from the Ministry of Higher Education with the grant number FRGS/1/2016/STG01/UITM/03/6. 


\section{References}

1. Xu, B., Liu, Y., Yin, X., Yang, W. and Chen, Y. (2013). Experimental and theoretical study of corrosion inhibit ion of 3-pyridinecarbozalde thiosemicarbazone for mild steel in hydrochloric acid. Corrosion Science, 74: 206213.

2. Dariva, C. and Galio, A. (2014). Corrosion Inhibitors-principles, Mechanisms and Applications. Developments in Corrosion Protection, 16: 365-378

3. Obot, I. B., Macdonald, D. D. and Gasem, Z. M. (2015). Density functional theory (DFT) as a powerful tool for designing new organic corrosion inhibitors: Part 1: An overview. Corrosion Science, 99: 1-30.

4. Saha, S. K., Ghosh, P., Hens, A., Murmu, N. C. and Banerjee, P. (2015). Density functional theory and molecul ar dynamics simulation study on corrosion inhibition performance of mild steel by mercapto-quinoline schiff ba se corrosion inhibitor. Physica E: Low-Dimensional Systems and Nanostructures, 66: 332-341.

5. Goulart, C. M., Esteves-Souza, A., Martinez-Huitle, C. A., Rodrigues, C. J. F., Maciel, M. A. M. and Echevarri a, A. (2013). Experimental and theoretical evaluation of semicarbazones and thiosemicarbazones as organic cor rosion inhibitors. Corrosion Science, 67: 281-291.

6. Kassim, K., Kamal, N. K. M. and Fadzil, A. H. (2016). Synthesis, characterization and electochemical studies o f 4-methoxybenzoylthiourea derivatives. Malaysian Journal of Analytical Sciences, 20(6): 1311-1317.

7. Yadav, M., Behera, D. and Kumar, S. (2014). Experimental and theoretical studies on corrosion inhibition of m ild steel in hydrochloric acid by thiosemicarbazone of schiff bases. Canadian Metallurgical Quarterly, 53(2): 2 20-231.

8. Daoud, D., Douadi, T., Hamani, H., Chafaa, S. and Al-noaimi, M. (2015). Corrosion inhibition of mild steel by two new $s$-heterocyclic compounds in $1 \mathrm{M} \mathrm{HCl}$ : Experimental and computational study. Corrosion Science, 94 : 21-37.

9. John, S., Jeevana, R., Aravindakshan, K. K. and Joseph, A. (2017). Corrosion inhibition of mild steel by N(4)-s ubstituted thiosemicarbazone in hydrochloric acid media. Egyptian Journal of Petroleum, 26(2): 405-412.

10. Rastogi, R. B., Singh, M. M., Singh, K. and Yadav, M. (2011). Organotin dithiobiurets as corrosion inhibitors f or mild steel- dimethyl sulfoxide containing HCl. African Journal of Pure and Applied Chemistry, 5(2): 19-33.

11. Kurniasih, H., Nurissalam, M., Iswantoro, B., Afriyani, H., Qudus, H. I., and Hadi, S. (2015). The synthesis, ch aracterization and comparative anticorrosion study of some organotin(IV). Oriental Journal of Chemistry, 31(4) : 2377-2383.

12. Rastogi, R. B., Singh, K. and Maurya, J. L. (2012). Synthesis and characterization of organotin(IV) thiobiurets. Synthesis and Reactivity in Inorganic, Metal-Organic, and Nano-Metal Chemistry, 42(4): 616-620.

13. Dzulkifli, N. N., Farina, Y. and Yamin, B. M. (2015). Dysprosium(III) isatin 2-methyl-3-thiosemicarbazone : S ynthesis, structural and characterization. Malaysian Journal of Analytical Sciences, 19(3): 541-549.

14. Netalkar, P. P., Netalkar, S. P., and Revankar, V. K. (2015). Transition metal complexes of thiosemicarbazone: Synthesis, structures and invitro antimicrobial studies. Polyhedron, 100: 215-222.

15. Sampath, K., Sathiyaraj, S., Raja, G. and Jayabalakrishnan, C. (2013). Mixed ligand ruthenium(III) complexes of benzaldehyde 4-methyl-3-thiosemicarbazones with triphenylphosphine/triphenylarsine co-ligands: Synthesis, DNA binding, DNA cleavage, antioxidative and cytotoxic activity. Journal of Molecular Structure, 1046: 8291.

16. Parrilha, G. L., Da Silva, J. G., Gouveia, L. F., Gasparoto, A. K., Dias, R. P., Rocha, W. R., Santos, D. A., Spez iali, N. L. and Beraldo, H. (2011). Pyridine-derived thiosemicarbazones and their Tin(IV) complexes with antif ungal activity against Candida spp. European Journal of Medicinal Chemistry, 46(5): 1473-1482.

17. Affan, M. A., Wan, F. S., Ngaini, Z. and Shamsuddin, M. (2009). Synthesis, characterization and biological stu dies of organotin(iv) complexes of thiosemicarbazone ligand derived from pyruvic acid: X-ray crystal structure of [ $\left.\mathrm{Me}_{2} \mathrm{Sn}(\mathrm{PAT})\right]$. Malaysian Journal of Analytical Sciences, 13(1): 63-72.

18. Venkatesh, K., Rayam, P., Sekhar, K. B. C. and Mukkanti, K. (2016). Synthesis, characterization and biological activity of some new thiosemicarbazide derivatives and their transition metal complexes. International Journal of Applied Biology and Pharmaceutical Technology, 7(1): 258-267.

19. Abdalla, O., Farina, Y. and Ibrahim, N. (2015). Synthesis, characterization and antibacterial study of copper(II) complexes of thiosemicarbazones. Malaysian Journal of Analytical Sciences, 19(6): 1171-1178.

20. Singh, H. L., Singh, J. B. and Sharma, K. P. (2012). Synthetic, structural, and antimicrobial studies of organotin (iv) complexes of semicarbazone, thiosemicarbazone derived from 4-hydroxy-3- methoxybenzaldehyde. Resear ch on Chemistry Intermediate, 38: 53-65. 
Nur Nadira et al: SYNTHESIS, CHARACTERISATION AND EFFECT OF TEMPERATURE ON CORROSION INHIBITION BY THIOSEMICARBAZONE DERIVATIVES AND ITS TIN(IV)

COMPLEXES

21. Hashim, N. N. Z. and Kassim, K. (2014). The effect of temperature on mild steel corrosion in $1 \mathrm{M} \mathrm{HCl}$ by schif $\mathrm{f}$ bases. Malaysian Journal of Analytical Sciences, 18(1): 28-36.

22. Badr, G. E. (2009). The role of some thiosemicarbazide derivatives as corrosion inhibitors for C-steel in acidic media. Corrosion Science, 51(11): 2529-2536.

23. Muralisankar, M., Sreedharan, R., Sujith, S., Bhuvanesh, N. S. P. and Sreekanth, A. (2017). N(1)-pentyl isatin$N(4)$-methyl-N(4)-phenyl thiosemicarbazone (PITSc) as a corrosion inhibitor on mild steel in HCl. Journal of A lloys and Compounds, 695: 171-182. 